Katie Barclay

Illicit intimacies: the imagined 'Homes' of Gilbert Innes of Stow and his mistresses (1751-1832)

Gender and History, 2015; 27(3):576-590

(C) 2015 John Wiley \& Sons Ltd

Originally published at: http://dx.doi.org/10.1111/1468-0424.12151

\title{
PERMISSIONS
}

https://authorservices.wiley.com/author-resources/Journal-Authors/licensing/selfarchiving.html\#1

Submitted (preprint) Version

The submitted version of an article is the author's version that has not been peer-reviewed, nor had any value added to it by Wiley (such as formatting or copy editing).

The submitted version may be placed on:

- the author's personal website

- the author's company/institutional repository or archive

- not for profit subject-based preprint servers or repositories

Self-archiving of the submitted version is not subject to an embargo period. We recommend including an acknowledgement of acceptance for publication and, following the final publication, authors may wish to include the following notice on the first page:

"This is the pre-peer reviewed version of the following article: [FULL CITE], which has been published in final form at [Link to final article using the DOI]. This article may be used for non-commercial purposes in accordance with Wiley Terms and Conditions for Use of SelfArchived Versions."

The version posted may not be updated or replaced with the accepted version (except as provided below) or the final published version (the Version of Record).

There is no obligation upon authors to remove preprints posted to not for profit preprint servers prior to submission.

4 September 2018 


\section{Illicit Intimacies: the Imagined 'Homes’ of Gilbert Innes of Stow and his Mistresses (1751-1832) $^{\text {i }}$}

Katie Barclay

In 1824, Mary Hutton, the mistress of the banker Gilbert Innes of Stow, wrote to him, reflecting on a decade of illicit intimacy:

You have been my pain, your eccentricity has distracted me. But I desire to send you the olive branch as a supplicant, Hail it Monsieur and we may still be as happy as Guilty creatures on the brink of eternity can be, You have been my pain, but I have lived only for you these ten years, the best of my life has passed in solitude I feel you part of myself and cannot renounce you, something from within assures me, that we must soon part, I alone am the sufferer, in the sight of God I am guilty and deserve Hell but in regard to you my conscience boldly calls out, not guilty! ${ }^{2}$

After ten years as the mistress of Gilbert Innes of Stow, Mary Hutton's affection had not diminished but the consequences of the transient lifestyle of a mistress in a society intolerant of sexual immorality, her increasing acceptance that Gilbert would never marry her, religious and financial anxieties and his waning affection worried her. In a remarkable correspondence 
that lasted over a decade, she worked hard to build a 'home' with Gilbert. Locating him in the role of absent husband, she looked to him as her economic provider, intimate friend, lover, emotional support and family, hoping that eventually her imagined home would be realised in marriage. Unfortunately for Mary, she was only one of Gilbert's many mistresses; nor was her strategy in writing Gilbert as absent husband unique to her. Configuring their illicit relationships as a form of marriage and locating Gilbert as a husband was a way that Gilbert's many 'wives' constructed their relationship within a context where narratives for illegitimate unions were rare. They created correspondences that on many occasions sat easily amongst the writings of their lawfully married contemporaries. Such moments of domestic normality were frequently fractured by the reality that Gilbert's absence was not temporary and that he was often unwilling to play husband.

Gilbert was one of many 'polite' men in Enlightenment Scotland who placed aside the moral and political scruples of their era and social class to have multiple 'families' or sexual partners and illegitimate offspring. He represents a fissure in the contemporary historiography of late eighteenth-century manhood. On the one hand, men of his social class are often understood by historians to place considerable emphasis on sexual and moral probity as the basis of masculinity and its contingent political rights; on the other, it has been argued that men's need for sex was given increasing emphasis during the period, the use of prostitutes appears to be growing, and the illegitimate children of this social group were used to further their interests in Empire. ${ }^{3}$ How men negotiated and lived these contradictions, if contradictions they were, and how this in turn should be interpreted by historians interested in patriarchal power is the subject of this article. Due to the limitations of space, this article seeks to explore this issue through the framework of Gilbert as an economic provider, using his, not always successful, performance of this key husbandly responsibility as a lens to understand how he related to his 'family' and the implications for middle-class manhood. In 
doing so, it recognises that this neglects the many other ways these letters give insight into Gilbert as 'husband', including his roles as a lover, friend, intimate and educator that intersected with that of provider.

Accessing 'Gilbert' is not straightforward. His absence as husband is mirrored in his absence within his own record. ${ }^{4}$ Gilbert left a copious archive, including thousands of letters, but most are addressed to him. ${ }^{5}$ His own writings are limited to his detailed account books, letterbooks that mostly relate to his business proceedings, the occasional personal letter that survives in the correspondence of his sisters, and the odd annotation on a piece of mail. How he conceived of himself as a 'husband', father and lover must be reconstructed through his correspondents' writings as they respond to his letters. ${ }^{6}$ This is possible due to the survival of a unique collection written by women who lived as Gilbert's mistresses. The largest surviving correspondence is that with Mary Hutton, a middle-class woman trained as a governess who met Gilbert outside St Andrew’s church in 1814 and remained his mistress until at least 1826. Unless seeing him regularly, she wrote to him every two or three days, leaving several hundred letters. There are also a significant number of letters from A. Alexander, probably a servant and later a washerwoman, and E. Crawford who was certainly middle-class and close friends with his larger family network. There are a smaller number of letters from a range of other women. Gilbert maintained significant correspondences with several of his children from these relationships, including the Burnets and Leslies, and William Maclaurin. Through their writings, Gilbert's relationships, how he was perceived by his family network and to an extent his motivations and desires can be reconstructed.

\section{Men at Home: Domesticity, Masculinity and Sex}


The connection between domesticity and sexual identity/ies is a topic of considerable debate within the eighteenth century. Whilst there is a general agreement of an increasing polarisation of ideas around male and female sexuality, closely linked to a discursive widening of public and private, active and passive, the extent of this shift and its implications for social practice is a topic of discussion. ${ }^{7}$ Debates originally focused on the consequences for women, where the move from sexually assertive to 'passionless' with the rise of the 'cult of domesticity’ over the long eighteenth century has been put under scrutiny. ${ }^{8}$ More recently, focus has turned to male sexuality, with historians exploring the relationship and tensions between models that promoted an 'active' male sexual desire whilst also demanding self control. ${ }^{9}$ Within such discussions, domesticity has become increasingly important to male as well as female sexuality, with Trumbach arguing that the growth of brothels in the late eighteenth century contained male heterosexuality in a safely 'domesticated' sphere. ${ }^{10}$ In this, male sexual preferences are seen to signal the importance of the domestic to men's social and political identities. ${ }^{11}$

The achievement of domestic manhood is increasingly viewed as central to the identities of all men, but particularly those from the middling sorts, who used it as evidence of their social and sexual stability, self-control and political maturity. ${ }^{12}$ The domestic is sited as a disciplining mechanism on the male, as well as female, body, reinforcing the importance of moral probity, sexual fidelity and monogamy to 'polite' identity. Following a much older tradition where the successful achievement of household head was a source of power for men in society more broadly, men's attainment of domestic manhood is seen to be implicated in their wider social and cultural authority. ${ }^{13}$ This was particularly true in Enlightenment Edinburgh, where the Kirk (i.e. the Church of Scotland) remained influential, conservative Christian values were mainstream, and where the performance of 'politeness', in which domesticity was central, was essential to men of all ranks. This was in no small part due to its 
role in conveying political power to individuals and to the nation, which used this conservative value system as evidence of Scotland's equality with England and readiness to engage in Empire. ${ }^{14}$

As it had been for several centuries, the household was situated as the nation writ small and the intimate located as a space of political as well as personal power. ${ }^{15}$ Eighteenth and early-nineteenth-century homes were fundamentally patriarchal, a space where men and women negotiated the terms and expression of their gendered roles within a framework of male authority and female subordination. ${ }^{16}$ This was reinforced during the period through the 'invention', or at least consolidation, of the concept of 'the home', a romanticised space of belonging and the seat of the self. ${ }^{17}$ The intimacy of family life was a core component of what made a house ‘a home'. Households of single people had greater difficulty constructing themselves as 'havens' of domesticity, partly as they were more economically vulnerable but also because 'the home' required both husband and wife. ${ }^{18}$ This intimate imagining of the household considerably blurred the line between 'the home' and the marital unit, with the emotional and practical investments in marriage and the home mutually reinforcing each other and the power structures embedded within the patriarchal marriage/household.

Whilst the home operated as a source of power for men, as well as a site of discipline, not all men conformed to the sexual expectations built within a normative understanding of 'homelife'. Despite a hardening of attitudes making illegitimate children less welcome in their father's homes and in polite society more broadly, the natural offspring of elite men played a crucial role in Empire. ${ }^{19}$ These children were often born in Britain to white women and strategically placed in Empire to further the family interest. As historians such as Laura Stoler have noted, white men's choices of which wives and children they acknowledged, and which they did not, were implicated in the construction of colonial power, as the boundaries of the family demarcated who was entitled to hold authority or even who should be accorded 
basic human rights. ${ }^{20}$ In this, the intimate became a 'critical site for the consolidation of colonial power', with wider social power relationships emerging through the intimate space of the home. ${ }^{21}$

Similarly, men’s sexual transgressions ‘at home’ have been located as a source or demonstration of social authority, whether that is in the gendered and class hierarchies that were built into the erotic imaginings of the period, or the use of pornography and promiscuity as a symbol of political power by the aristocracy and its radical opposition. ${ }^{22}$ Of course, the constraints on men 'at home' were distinctly different from those in Empire. The reality of the sexual double standard, where men had considerably more sexual freedom than their female counterparts, was curtailed by the importance of an appearance of sexual probity to middling and increasingly elite and aristocratic identity and 'the home' as a location of male power. ${ }^{23}$ Yet, whilst this is acknowledged, how the political imagining of 'domesticity' and the 'home' acted to restrain men's sexuality has been underexplored, as has the implications of sexual misbehaviour for men's social authority. Some Scottish men fantasised about the erotic possibilities of being a Sultan over a vast harem or an Old Testament patriarch with many wives. ${ }^{24}$ Such erotic imaginings were perhaps realised by the numerous men who kept mistresses and fathered illegitimate children during this period. How such men co-existed with this conservative society, negotiated their illegitimate relationships, and understood the source of their social power has not been explored. It is to one such man and his many mistresses that we now turn.

\section{Gilbert Innes of Stow (1751-1832): A Biography}

Gilbert Innes of Stow (1751-1832) was born into an established and upwardly mobile banking, legal and merchant family in the east of Scotland. ${ }^{25}$ He was tied by blood and marriage into the merchant elites of both Aberdeen and Edinburgh, with strong connections 
in Empire, particularly through the descendants of his great-uncle Alexander Innes of Cathlow, who made his fortune through sugar, slavery and imports. Gilbert's branch of the family focused their energies into the law, banking and sugar production. Trained as a 'writer' (solicitor), his father George Innes worked his way up to Cashier of the Royal Bank, a senior management position, established a fortune, purchased the estate of Stow in Peebleshire and married Marion Lauder (1711-43), the daughter of David Lauder of Huntleywood, a member of an established Edinburgh merchant and legal family. ${ }^{26}$

Gilbert Innes of Stowe was George’s eldest son. He was placed in the Royal Bank of Scotland, alongside his father, uncle Alexander, his cousins James Innes (d. 1806) and William Simpson (1742-1808, son of George’s sister Isobel), and his second cousins George and William Mitchell (grandsons of George’s sister Isobel). All of these men rose to senior leadership roles within the bank. Gilbert eventually advanced to Deputy-Governor, the highest operative role. He supplemented his income through trading imports, whilst his estate, inherited from his father in 1780, supplied him with rents and farm produce. He was extremely wealthy.

Gilbert was a central figure within Edinburgh’s ‘polite’ society. 'Politeness’ was a key ideal amongst elite Scots, tying together a range of outward behaviours, including dress, manners and education, with the Enlightenment values of sociability, improvement and cosmopolitanism. It was an ideal performed in sociable, urban spaces from the tea-table to the ballroom and theatre. ${ }^{27}$ Innes played a key role in local governance as a Deputy-Lieutenant of Edinburgh, actively promoted the Enlightenment ideal of 'improvement' as manager of the Edinburgh Infirmary, a member of the Board of Manufacturers, and treasurer of both the Highland Society and the Pitt Club of Scotland. He played a central role in polite and associational culture including as a director of Edinburgh's particularly large and exclusive Musical Society and of the Society of Antiquaries, a member of the more convivial Catch 
Club, and as a director of the Edinburgh Assembly Rooms, the location of public balls. ${ }^{28} \mathrm{He}$ invested his immense wealth in charitable enterprises and was an enthusiastic patron and purchaser of the arts.

As well as placing him at the heart of Edinburgh society, these roles gave Gilbert considerable power to shape Edinburgh’s moral culture. Most Enlightenment associations had rules of conduct that reinforced appropriate gendered and sociable behaviour. Whilst male homosocial societies perhaps did not enquire too closely into the behaviour of its members beyond their doors, The Assembly Rooms had a code of conduct for dancers that regulated behaviour, clothing and other moral concerns. As Rosalind Carr notes, the enforcement of such codes was intended as an active demonstration of 'moral probity'. ${ }^{29}$ In practice, this code of conduct was enforced by the 'Lady Directresses', elite women who oversaw the decorum of such events but did not sit on the board. ${ }^{30}$ Yet, through their codes of conduct as well as their decisions over membership and musical entertainment, directors, like Gilbert, demonstrated their investment in the moral dimensions of 'polite' society.

Despite this, Gilbert, alongside many of the Scottish Enlightenment’s male elite, did not apply polite codes of morality to his own behaviour outside of these public forums. He was an inveterate gambler and philanderer. Across his life, thirty-two women can be identified as mistresses in his correspondence. ${ }^{31}$ Many of these relationships were of significant duration and overlapped with each other. Effie Burnet bore him at least eight children; she also fostered at least two of his children to different mothers. Catherine Leslie had at least six. A. Alexander maintained a relationship and correspondence with Gilbert for over a decade. Mary Hutton’s relationship had lasted for twelve years when the surviving correspondence ends and it may well have continued til his death in 1832 . They had no children. His archive evidences his maintenance of at least twenty-five illegitimate children, and when he died intestate sixty-seven children laid a claim on his estate. ${ }^{32}$ 
Gilbert did not marry, living with his two never-married sisters until 1809 when Jane moved out following Marion's death in $1799 .{ }^{33}$ Their father showed some resistance to their marrying, which may have prevented them in their early years - but as Alison Duncan has shown, never-marrying was not atypical of this social class during this period. ${ }^{34}$ Whilst his sisters and possibly much of Edinburgh society were aware that Gilbert's behaviour was not always upstanding, the scale of his activities does not appear to have been widely known. 1793 was a crisis point. Effie Burnet died and Gilbert decided to take their children under his direct care, locating them in a house near to the family home. In doing so, he openly broadcast his improprieties to Edinburgh society and threatened his sisters' genteel status. Not without some grumbling, his sisters became the main overseers of these children.

The consequences for Gilbert’s reputation does not appear to have been significant, possibly because the Burnets were politely educated and integrated into the margins of polite society and because there was a tradition of Scottish single men having 'housekeepers' that may have meant that many Scots excused this relationship as an 'irregular' family (still recognised in law in Scotland), rather than a symbol of Gilbert's sexual sin. ${ }^{35}$ This event caused Jane to start an investigation into Gilbert's activities, writing anxiously to her wider kin as the extent of his sexual wrongdoing came to light. By 1800, members of her family were advising her to leave his house due to the jeopardy to her own reputation, suggesting that Gilbert's antics were increasingly public. Yet, his correspondence indicates that he monitored public appearances more rigidly than his sisters believed. His mistresses and many of his children were prohibited from visiting and writing to his home, directing mail to the nearby post office. ${ }^{36}$ If he passed them in the street, he frequently did not acknowledge them, often to their chagrin. ${ }^{37}$ The efforts that he and his lovers put into keeping their activities secret from nosy neighbours and landlords suggests that it was not just women's reputations that were at stake. The women themselves were certainly aware that Gilbert had illegitimate 
children and many suspected that he had other relationships; whether they could identify each other is less clear. It is not clear that Gilbert actively suffered as a result of his behaviour. His civic roles continued until his death. If his social circle reduced, it is not evident from his correspondence.

Gilbert's behaviour was perhaps extreme, but not unique, living contemporaneously to men such as George, Lord Byron and Giacomo Casanova with whose reputations and writings it was likely Innes was familiar. His father, George, had two illegitimate children born from relationships with servants previous to marriage, although both had died before Gilbert was twelve. His fellow director on the board of the Assembly Rooms and well-known jurist, Gilbert Elliot, 1st Earl of Minto had eight children with his mistress Mrs Barry, as well as a legitimate family. ${ }^{38}$ His friend, the lawyer and diarist, James Boswell had at least two illegitimate children, five surviving legitimate children and his diaries evidence that his sex life was at least as messy as Gilbert's. ${ }^{39}$ Gilbert was not alone in having a number of children whilst never marrying. The author of the Ossian poems, James Macpherson had five illegitimate children, but remained single. ${ }^{40}$ Whilst this group of men were elite and central figures of Enlightenment society, they were not part of the lascivious aristocracy that perturbed the imagination of the period, nor were they sex radicals or the bohemian fringe. ${ }^{41}$ They were at the heart of a social group who were actively situating sexual morality as a key dimension of male political identity. ${ }^{42}$ How men like Gilbert reconciled this contradiction in the shaping of their sense of self was not straightforward, as the anxiety that pervades Boswell's famous diary indicates.

Reflecting his investment in politeness, Boswell's anxieties resulted from his unmanly inability to exercise self-control over his desire. Over his life, he repeatedly imagined himself into alternative masculinities, including 'blackguard', 'Asiatic ruler', and 'Biblical patriarch' as he attempted to find a model for his promiscuous sexual drive. ${ }^{43}$ Whether Gilbert saw his 
behaviour as unmanly is not evident, although like Boswell, it clearly required him to resist some social norms. Despite attending church, Gilbert did not hold a conventional belief in God, allowing him to place aside moral anxieties around divine punishment. ${ }^{44}$ This 'unbelief' perplexed his mistress Mary Hutton, although the form it took is unknown. What is more evident is that Gilbert seems to have resisted the obligations that arose from family life, refusing the formal responsibilities, and to extent the authority, that arose from marriage.

\section{Imagining Gilbert as Economic Provider}

The ability to provide for a family was a central dimension of masculinity across the period, a duty required of husbands, a marker of respectability, and a symbol of political maturity. ${ }^{45} \mathrm{In}$ practice, women's labour, earnings and other income were important to many households at all social levels and women's paid work often expected, but provisioning was less central to models of femininity. ${ }^{46}$ Increasingly, it was women's work within the domestic space that was key. Women's ability to make a house not only a home but a haven from the external world imbued the imagery of the domestic and women’s work within it with a romantic, affective quality. ${ }^{47}$ Moreover, as home-making and marriage-making were closely connected, women's work in creating the home became an act of love for their spouse - the outward representation of their affection. Similarly, economic provision by husbands, embedded within the wedding vows, had long been understood to represent husbandly love. ${ }^{48}$ Here the legal duties placed upon a husband to provide for his wife and children were articulated and justified through a framework of natural affection, collapsing the distinction between love and economic obligation. ${ }^{49}$

Gilbert's provisioning was a central theme within his correspondence, reflecting that it was his finances that maintained many of his mistresses and children either completely or in part, but also that it was a key dimension of marriage. His decision to finance these 
families was his central form of acknowledgement, and was not automatic - some women had to threaten court proceedings for child support before he would come to a settlement. ${ }^{50}$ Illegitimate children were entitled to financial support until they were old enough to work, but had no legal claim to inherit paternal property, unless it was willed to them. ${ }^{51}$ As this suggests, whether Gilbert acknowledged a mistress or child was not entirely within his control. Likewise, whilst Gilbert often resisted both the responsibilities and the affective connotations of his economic role, the strength of the cultural link between provision and love meant that these emotional connections were not easy to resist.

Both Gilbert and his mistresses had a shared understanding that a sexual relationship entailed a financial and emotional outlay from Gilbert, although the nature and extent of the commitment was open to debate. The economic expectation was partly supported by law. Men were obliged to compensate women for the expenses incurred through lying-in, nursing and raising their children. ${ }^{52}$ But, Gilbert and his mistresses also conceived of the sexualfinancial relationship as incurring a reciprocal obligation that went beyond the financial, similar to that of the provisioning husband and the sexually-available wife. On the one hand, his mistresses' expectation of financial support was clearly viewed as an entitlement, or earning, as much as an act of generosity from Gilbert. Requests for money were often done without ceremony as was the case for wives of the period: 'It will take $£ 6$ to clear me here I think, will you send me $£ 7$ my dear sir, least I should be short and I will give you an account of it when we meet', asked Mary Hutton in $1821 .{ }^{53}$ When A. Alexander asked for some spoons and Gilbert felt her greedy, she apologised but noted grumpily: 'I forgot that my acquaintince was too long and owld and my self out of deate to expect such an honour, but I was not aware but I might use as much freedom with the man I had loved and so well and so well [sic] and so long'.54 
Yet, whilst his long-term mistresses understood their provision of sexual services to require payment, they were deeply conscious of the implications this had for their reputations as 'whores'. This could require them to explicitly distance themselves from the imputation of prostitution. Grizell Campbell wrote angrily to Gilbert after he refused to pay the costs of nursing their son: 'you was so Un greatfull as to desire me to take home the boy your son \& to prostitute my body to your pleasure but as I would not consent to become your whore and humble my body to your pleasure you said you would not pay me the money'. ${ }^{55}$ Grizell accused Gilbert of attempting to tarnish their relationship by 'prostituting her body', and saw his removal of payment for her childcare as a punishment for her removal of sexual services. In making this explicit, she sought to distinguish her place as a mother and (now ex) mistress from that of a common prostitute, through both claiming her financial entitlement as a mother and through her display of sexual autonomy. That illicit sex was so closely tied to prostitution in the imagination of the period was clearly problematic for these women's self-presentation. They understood the provision of sexual services outside marriage - with or without financial payment - as a sin and a form of prostitution, something encouraged by the Kirk in their semantic linking of fornication and whoredom. But, their letters indicated that this was a difficult label for them to wear.

Instead of viewing themselves as prostitutes, his mistresses located their sexual activities within a framework of marriage, embedding both Gilbert's economic provision and their sexual services as an affective exchange that could exceed the mundane. A. Alexander begged to see him after an absence of several weeks, noting 'I am not asking you to take any care of me give me only the pleasure to see you some times which will be meat and drink to me'. ${ }^{56}$ Whilst like Campbell, Alexander clearly recognised that Gilbert's economic provision was tied to his sexual interest, she believed that their love created an intimacy that extended beyond the course of their sexual relationship and entailed obligations that lasted into old age. 
These were obligations that Gilbert often resisted, neglecting to visit and pay maintenance, and yet he often found himself reconnecting with these long-term mistresses and moving back into his role as 'husband' as a sense of responsibility pulled him back into an affective tie. Whilst during Gilbert's absences Alexander plead only for his company, her requests for financial support were reinvigorated by his return. This was not necessarily because Alexander's claim that love was all she needed was cynical, but rather reflected that as economic provision was evidence of a husband's love, in practice it was difficult to imagine a loving relationship where Gilbert did not play that role.

Unlike some of Gilbert's mistresses, Alexander was previously a servant and expected to earn for herself, something she may well have done had she married. She continued to labour, usually at washing and sewing, throughout their relationship, using Gilbert's income as a partial maintenance. Gilbert suggested that Mary Hutton might supplement her income with earnings, and at one point she got 'some very pleasant work from a Manufacturer', but found it hurt her eyes after a couple of days. ${ }^{57}$ As she reminded him repeatedly, she was middle class and he had ruined her character, ensuring that she was disowned by her family (and so lost her father's financial support) and was unable to earn in her profession as governess: 'Ah monsieur I had a comfortable Home, abundance of friends \& acquaintances this day 11 years ago, and a spotless character Alas! Alas! These are all gone long ago'. ${ }^{58}$ Her expectation for maintenance was considerably higher than that of Alexander, and she did not expect it to diminish as the relationship aged. Gilbert does not appear to have challenged this basic assumption, although clearly Mary’s expenditure was a source of tension. They argued over whether her father would have maintained her at this level; whether the inheritance of 'a few $£ 100$ ’ that she lost due to her relationship would have stretched as far as Gilbert’s maintenance; what type of housing he was prepared to pay for, and whether she could contribute to her household. ${ }^{59}$ 
It is unlikely that Gilbert would have expected his wife to work for money; neither his mother nor his unmarried sisters did so, reflecting their genteel status. Suggesting that his mistresses work, as well as his decision to put many of his female children into trade apprenticeships, was a key way in which he reminded them and himself of their illegitimate status, and the limits of his love ${ }^{60}$ It demonstrated his duty of care and affection through providing them with a method of future support, but denied them the status of a legitimate child or wife. Mary was clearly aware of this and resisted being pushed into work: 'you affect to consider me a low women who aspires to genteel things then I have any right too but it is well known how I was brought up and the society I had lived in until I became acquainted with you' ${ }^{61}$ She frequently insisted that the only occupation for a woman of her status, without a trade and without character was prostitution, strategically locating herself in the role of a victim in a sentimental novel. ${ }^{62}$ Gilbert appears to have actively rejected this presentation of her circumstances (Mary acknowledged he had never promised her marriage), but it was an effective way of getting him to produce money. Even as he distanced himself from the role of seducer, he felt her claim was compelling, stimulating his affectionate provisioning. ${ }^{63}$

In this, as with Gilbert's tendency to drift back into relationships that had previously petered out, there is a sight of how he reconciled the contradictions of his multiple mistresses with his sense of 'polite' manliness. He actively rejected the role of seducer and not only asserted his mistresses' sexual agency, but encouraged them to be financially independent. In doing so, he reimagined his familial relationships into a contract between independent adults, rather than one based on the patriarchal household. However, as the nature of his affective ties placed him to the role of husband and father, or occasionally seducer, he was forced to recognise the traditional duties associated with these roles. That he usually fulfilled these duties (if to varying extents) is suggestive of the centrality of the proper performance of 
patriarchal manhood to his sense of masculinity. Whilst he tried to justify his behaviour through imagining a new form of sexual contract, he was not able to reject the more traditional expectations of polite manliness that required him to protect and support vulnerable womanhood.

Gilbert's accounts suggest that he was a generous man willing to purchase expensive gifts for his family, but he resisted the formal long-term responsibilities that functioned as a requirement, rather than an offering. This was reflected in other areas of his life, where he did not always consider the domestic obligations upon those around him. His sister Jane complained on one occasion when he asked her to meet him en route from London that 'To leave your House empty set out upon a few hours warning ... was a proposal which I can receive in no other light than a showy substanceless suggestion of the moment' ${ }^{64}$ His relationships with his sons, William MacLaurin and George Burnet, was particularly difficult as they, like many other sons of the era, contested the nature of his support for them as young men. In this case, however, Gilbert required his sons to show greater independence than was perhaps practicable, giving them polite educations but less willing to make the formal introductions that would place them in professional occupations. ${ }^{65}$ He also tired of managing his many mistresses on occasion, failing to write and even to read their letters. ${ }^{66}$

Perversely given this, Gilbert exerted considerable control over those he supported. He kept detailed accounts of all his expenditure and also required it of those children and partners that he financially supported. Given the anxiety that many of his dependents expressed when their accounts did not add up or went missing, Gilbert was very particular about this record-keeping and it was a way to monitor the lives of his dependents closely. Mary Hutton begged of him: 'Do not be very strict in looking over the Acct, I could explain, if I were by, what may appear to you irregular, so I beg you not to take offence'. ${ }^{67}$ His son William Maclaurin felt that his father used them as an excuse to criticise: 'My accounts 
though strictly examined were indeed seldom found fault with, but I was dinned incessantly for sending them in when sometimes it was not in my power' ${ }^{68}$

Financial mismanagement by his dependents made Gilbert reluctant to make further maintenance payments, requiring them to cooperate with his demands. This gave him considerable power over their everyday lives and, despite his unwillingness to fully take responsibility for his family, he was often reluctant to allow them to pursue active lives beyond him. ${ }^{69}$ This may have motivated his hesitancy in enabling the careers of William and George. William went as far to complain that he could not find work due to 'an awkward diffident timidity which I cannot shake off, the consequence of a life of dependence \& restraint'. ${ }^{70}$ Gilbert was distressed when his Burnet daughters married, making awkward and usually vague protestations about delaying that angered and upset them before he finally agreed. $^{71}$

Gilbert's control over his dependents was partly born of his affection. Mary Hutton, rather spitefully noted during an argument that: 'In revenge for your ill natured letter I wish your daughter may get a hilland husband in Ireland and keep you sobbing and sighing like you did when her sister married'. ${ }^{72}$ But, it was rooted in a belief that his economic provisioning placed him into a position of authority over those he supported. In this, Gilbert's loving control was an extreme form of the fatherly and husbandly love idealised during the era, where love was both an act of male power and the exercise of benevolent self-control of that power - a love that required affectionate care, provision and discipline. ${ }^{73}$ It was not unique to him, learned from his father and modelled by other anxious parents and husbands throughout the country. ${ }^{74}$ Determining the balance of power between parent and child was a topic of ongoing debate. Whilst it was expected that parents should set their sons in appropriate careers and their daughters in good marriages, it was still viewed as a parental prerogative. 
Power should have operated slightly differently in marriage. While contemporary models of love required wives to subsume their selves into their husbands and to accept his authority, such oversight of a wives' behaviour should have been accompanied by Gilbert's reciprocal fulfilment of his duties as husband. In practice, management of the household budget was usually left to wives and considerable interference was viewed as a lack of trust that was detrimental to the marital union. ${ }^{75}$ Gilbert's mistresses had very little leverage to counteract his control; they could not demand greater trust or authority as 'wives'. Nor was their financial support required by law, especially after their children were old enough to work. This placed them at a significant disadvantage that reinforced Gilbert's power within the relationship at their expense. At the same time, Gilbert's wish to control his dependents acted to constrain his power. Even as he attempted to distance himself from the responsibilities and affections of 'husband' and 'father', his desire to manage his money placed him into these roles and embedded him firmly into this family network.

In doing so, this model for loving placed constraints on Gilbert's sexual activities through obliging him to support his illegitimate families as evidence of his love, and conversely, stirring and rejuvenating love through his fulfilment of his duties. When Effie Burnet died in 1793, leaving eight of his children motherless, Gilbert noted to his sister that: 'I never thought I cared much for them till they had nobody else to take Charge of them' ${ }^{76}$ In the following years, his relationship with these children became particularly strong and he retained ties with them into adulthood and later as a doting grandfather to their children. Obligation and affection were deeply intertwined for Gilbert, most straightforwardly visible in his greater willingness to support his mistresses when his affection was at its height, but also when reminders of obligation rejuvenated Gilbert’s affection. Emotion was generated through action. 
'Home-making' with Gilbert provided his mistresses an opportunity to reaffirm and restore affection, providing them with limited agency within the relationship. Due to the relationship between economic provision and love, the more interest Gilbert took in his dependent's spending, the more he embedded himself within their homes. How Gilbert's money was expended formed a central part of the correspondence he received. 'This is the way I have laid out the $£ 5$ you gave me for Clothes. A gown $£ 2 / 2$ Bonnet $£ 2 / 4$ shoes $7 /$ gloves 2/- material for corsets which I am to make myself 8/6', noted Mary Hutton, before asking for further money as she was 'bare of cloaths'. ${ }^{77}$ After she made her purchases, she wrote of how she wished he could see 'how pretty and well chosen my things are. My bonnet is a little gay, but nothing else. It is of worked thread and one feather stand colour lying over the front to the side and no ribbon except strings to tie it[.] my two dresses are both dark coloured'. ${ }^{78}$

As well as allowing his dependents to evidence their appropriate expenditure of Gilbert's resources, such accounts enabled his mistresses to imagine a 'home'. Hutton described her clothing and household purchases in detail, giving colours and fabrics as well as prices. She lamented his absence and desired that he could see her, using her detailed descriptions to give him access to the 'home' she was creating through her successful expenditure. She situated Gilbert as husband and household head, approving her domestic management. A. Alexander wrote to Gilbert: 'be so kind as fetch the pateron stocking to morrow night if you are come here[.] proud should I be of the honour of knitting once more one pare of stockings to you it would put me in mind of former and more happy days[.] days that never can return'. ${ }^{79}$ In trying to rebuild their fading relationship, Alexander created a vivid image of herself as a wife taking pleasure and pride in performing a domestic function for her husband. Work that, especially for a woman of her social background, would have signified her usefulness, economic prudence and her affection for her spouse. As Alexander 
acknowledged, the imagery of the wife darning her husband's stockings was laden with the ideal of domestic harmony and 'happy days'. By accepting this invitation, Gilbert realised this happy vision of domesticity, despite himself.

\section{Gilbert at Home: Conclusions}

As Stoler notes, the intimate is a critical site for the consolidation of social and political power. It is also a site that constrains it, gives it shape and intensifies it. Gilbert's many homes were shaped not only by his own choices, but constrained by a highly conservative society where his promiscuous sexual behaviour reflected poorly on his manliness; a model for 'home-making' and 'marriage-making' that guided Gilbert's obligations and emotions into those informed by a conventional model for 'marriage' even as he resisted it; and by the agency that his 'wives' exercised in utilising these constraints to guide his actions. Moreover, playing the role of 'husband' allowed Gilbert to reconcile some of the contradictions of his behaviour within a socially and sexually-conservative space. His ability to fulfil the expected economic responsibilities towards his family, ensuring that they were not left vulnerable to exploitation or a social burden, enabled him to perform one version of the conservative manly ideal of his age, whilst his lack of belief in God removed the moral burden of his behaviour. In this way, the intimate disciplined men into the ideal middle-class model of masculinity, that was also the seat of their wider political power. In constraining the individual, the intimate also acted to empower such men, reinforcing the political structures of the period.

At the same time, that Gilbert managed to behave so badly with relatively little consequences for his own social authority evidences the extent to which elite men's behaviour went unscrutinised. This is perhaps epitomised in his sister Jane's shock when she began to investigate his affairs in 1793: the evidence, found in his correspondence and accounts, had always been there, but nobody had chosen to look too closely. Here, Gilbert 
can be contrasted with his female partners, who were regularly forced to move homes when their sexual activities came to the attention of the relentlessly nosey Edinburgh community. The way that the intimate refracted these wider gender and class power dynamics can also be seen in Gilbert's treatment of his mistresses from different social levels. The amount of financial support, respect and even affection he offered his mistresses was directly related to their social background, articulating and reinforcing the class divisions within Scottish society. Moreover in asking women like Mary Hutton to work, Gilbert used these divisions to demarcate the limits of his affection and responsibility, simultaneously emphasising that his mistresses' sexual 'misbehaviour' had reduced their status whilst reinforcing his own. In this sense, the intimate intensified social power relationships, reaffirming white, male patriarchal privilege at the expense of those they 'loved'.

This research was funded by the Australian Research Council, DE140100111

\footnotetext{
${ }^{1}$ With thanks to the Gender \& History 'Men at Home' participants for their useful comments and stimulating papers, and Rosi Carr and the anonymous reviewers for their helpful feedback.

${ }^{2}$ National Register of Scotland [hereafter NRS] GD113/5/487/96 Mary Hutton to Gilbert Innes, 16 June 1824.

${ }^{3}$ Matthew McCormack, The Independent Man: Citizenship and Gender Politics in Georgian Britain (Manchester: Manchester University Press, 2005), pp. 87-8; Margot Finn, 'Family Formations: Anglo India and the Familial Proto-State', in David Feldman and John Lawrence (eds), Structures and Transformations in Modern British History (Cambridge: Cambridge University Press, 2011), pp. 100-17; Rosalind Carr, Gender and Enlightenment Culture in Eighteenth-Century Scotland (Edinburgh: Edinburgh University Press, 2014).
} 
${ }^{4}$ For an extended discussion of how space informs this dynamic, see Katie Barclay, 'Marginal Households and their Emotions: the 'Kept Mistress’ in Enlightenment Edinburgh', in Sue Broomhall (ed.), Spaces for Feeling: Emotions and Sociabilities in Britain, 1650-1850 (London: Routledge, 2015), pp. 95-111.

${ }^{5}$ His archive is stored by the National Register of Scotland at GD113 Innes of Stow. It is organised chronologically by date, so the letters from his family are interspersed amongst the entire collection.

${ }^{6}$ For a detailed discussion see Katie Barclay, Love, Intimacy and Power: Marriage and Patriarchy in Scotland, 1650-1850 (Manchester: Manchester University Press, 2011), introduction.

${ }^{7}$ Karen Harvey, 'The Century of Sex? Gender, Bodies, and Sexuality in the Long Eighteenth Century’, Historical Journal, 45 (2002), pp. 899-916.

${ }^{8}$ Nancy Cott, 'Passionlessness: an Interpretation of Victorian Sexual Ideology, 1790-1850', Signs 4 (1978), pp. 219-36; Harvey, 'Century of Sex’.

${ }^{9}$ A useful summary: Karen Harvey, 'The History of Masculinity, circa 1650 to 1800’, Journal of British Studies, 44 (2005), pp. 296-311.

${ }^{10}$ Randolph Trumbach, ‘Erotic Fantasy and Male Libertinism in Enlightenment England’, in Lynn Hunt (ed.), The Invention of Pornography: Obscenity and the Origins of Modernity, 1500-1800 (New York: Zone Books, 1993), p. 265.

${ }^{11}$ Karen Harvey, The Little Republic: Masculinity and Domestic Authority in EighteenthCentury Britain (Oxford: Oxford University Press, 2012); John Tosh, A Man’s Place: Masculinity and the Middle Class Home in Victorian England (New Haven: Yale University Press, 1999); Amy Milne-Smith, 'A Flight to Domesticity? Making a Home in the Gentleman’s Clubs of London, 1880-1914’, Journal of British Studies, 45 (2006), pp. 796818. 
${ }^{12}$ Anna Clark, The Struggle for the Breeches: Gender and the Making of the British Working Class (Berkeley: University of California Press, 1997).

${ }^{13}$ Alexandra Shepard, The Meanings of Manhood in Early Modern England, 1560-1640 (Oxford: Oxford University Press, 2003).

${ }^{14}$ Katie Barclay, 'Sex, Identity and Enlightenment in the Long Eighteenth Century’, in Jodi Campbell, Elizabeth Ewan and Heather Parker (eds), Shaping Scottish Identity: Family, Nation and the World Beyond (Guelph: Guelph University Press, 2011), pp. 29-42; Carr, Gender and Enlightenment.

${ }^{15}$ Rachel Weil, Political Passions: Gender, the Family and Political Argument in England, 1680-1714 (Manchester: Manchester University Press, 2001); Harvey, The Little Republic.

${ }^{16}$ For an extended discussion of the meaning of patriarchy, see Barclay, Love, Intimacy.

${ }^{17}$ Scott R. MacKenzie, Be It Ever So Humble: Poverty, Fiction, and the Invention of the Middle-Class Home (Charlottesville: University of Virginia Press, 2013).

${ }^{18}$ Alison Duncan, ““Old Maids”: Family and Social Relationships of Never-Married Scottish Gentlewomen, c. 1740-c.1840’, PhD Thesis, University of Glasgow, 2012, pp. 25-56; David Hussey and Margaret Ponsonby, The Single Homemaker and Material Culture in the Long Eighteenth Century (Aldershot: Ashgate, 2013), p. 51.

${ }^{19}$ Barclay, 'Sex’; Finn, 'Family Formations’.

${ }^{20}$ Ann Laura Stoler, 'Intimidations of Empire: Predicaments of the Tactile and Unseen’, in Ann Laura Stoler (ed.), Haunted by Empire: Geographies of Intimacy in North American History (Durham: Duke University Press, 2006), p. 2; Tony Ballantyne and Antoinette Burton (eds), Moving Subjects: Gender, Mobility and Intimacy in an Age of Global Empire (Urbana: University of Illinois Press, 2009).

${ }^{21}$ Stoler, 'Intimidations’, p. 4. 
${ }^{22}$ Karen Harvey, Reading Sex in the Eighteenth Century: Bodies and Gender in English Erotic Culture (Cambridge: Cambridge University Press, 2004); Anna Clark, Scandal: the Sexual Politics of the British Constitution (Princeton: Princeton University Press, 2003). ${ }^{23}$ Keith Thomas, 'The Double Standard’, Journal of the History of Ideas 20 (1959), pp. 195216; Bernard Capp, 'The Double Standard Revisited: Plebeian Women and Male Sexual Reputation in Early Modern England', Past and Present 162 (1999), pp. 70-100.

${ }^{24}$ Joanne Bailey, Parenting in England 1760-1830: Emotion, Identity and Generation (Oxford: Oxford University Press, 2012); Hugh M. Milne (ed.), Boswell’s Edinburgh Journals 1767-1786 (Edinburgh: Mercat Press, 2001), p. 34.

${ }^{25}$ A brief biography: ‘Gilbert Innes’, Royal Bank of Scotland Heritage Hub, <http://heritagearchives.rbs.com/people/list/gilbert-innes.html>; the following account has been constructed through analysis of NRS GD113 Innes of Stow.

${ }^{26}$ NRS GD113/5/77 Papers relating to the marriage settlement of Mr George Innes, 1743.

${ }^{27}$ Katherine Glover, Elite Women and Polite Society in Eighteenth-Century Scotland (Woodbridge: Boydell and Brewer, 2011), pp. 3-4.

${ }^{28}$ Simon McVeigh, 'Introduction', in Susan Wollenberg and Simon McVeigh (eds), Concert Life in Eighteenth-Century Britain (Aldershot: Ashgate, 2004), p. 6.

${ }^{29}$ Carr, Gender and Enlightenment, pp. 108.

${ }^{30}$ Carr, Gender and Enlightenment, pp. 105-9.

31 This was determined by a close analysis of his archive GD113.

32 'Gilbert Innes'.

${ }^{33}$ For a detailed analysis of Gilbert’s relationship with his sisters, see Duncan, 'Old Maids’, pp. 179-212.

${ }^{34}$ Duncan, 'Old Maids’. 
${ }^{35}$ Irregular marriages were those that did not conform to church procedures for marriage but were nonetheless legal in Scotland: Leah Leneman, 'House-Keeping in Eighteenth-Century Edinburgh', Scottish Local History 33 (1995), pp. 8-10. One anonymous writer suggests that Gilbert disguise the Burnet’s illegitimacy through giving them his name: NRS

GD113/5/457/145 Anonymous to Gilbert Innes, 13 October 1807.

${ }^{36}$ For a discussion on keeping letters secret see NRS GD113/5/487/49 MP [Mary Hutton] to Gilbert Innes, 3 May 1824.

${ }^{37}$ NRS GD113/5/489 MP to Gilbert Innes, 25 October 1824; GD113/5/482/70 A. Alexander to Gilbert Innes, 8 May 1822.

${ }^{38}$ Finn, 'Family Formations’, p. 111

${ }^{39}$ Gordon Turnbull, ‘Boswell, James (1740-1795)’, Oxford Dictionary of National Biography (Oxford: Oxford University Press, 2004; online edn, May 2006) $<$ http://www.oxforddnb.com/view/article/2950>.

${ }^{40}$ Derick Thomson, 'Macpherson, James (1736-1796)', Oxford Dictionary of National Biography (Oxford: Oxford University Press, 2004; online edn, May 2006) <http://www.oxforddnb.com/view/article/17728>.

${ }^{41}$ Clark, Scandal.

${ }^{42}$ McCormack, The Independent Man, pp. 87-8.

${ }^{43}$ Philip Carter, ‘James Boswell’s Manliness’, in Tim Hitchcock and Michele Cohen (eds), English Masculinities 1660-1800 (London: Longman, 1999), pp. 111-30; Barclay, 'Sex’. ${ }^{44}$ GD113/5/487/49.

${ }^{45}$ Clark, The Struggle for the Breeches; Harvey, The Little Republic.

${ }^{46}$ Amy Erickson, 'Married Women’s Occupations in Eighteenth-Century London’, Continuity and Change 23(2) (2008), pp. 267-307; Katie Barclay, 'Farmwives, Domesticity and Work in Late-Nineteenth-Century Ireland', Rural History 24(2) (2013), pp. 143-60. 
${ }^{47}$ Bailey, Parenting in England, pp. 116-7.

${ }^{48}$ Barclay, Love, Intimacy, p. 155.

${ }^{49}$ Katie Barclay, 'Natural Affection, Children and Family Inheritance Practices in the LongEighteenth-Century', in Elizabeth Ewan and Janey Nugent (eds), Children and Youth in Medieval and Early Modern Scotland (Woodbridge: Boydell and Brewer, Forthcoming 2015).

${ }^{50}$ NRS GD113/5/464/161 Grizel Campbell to Gilbert Innes, 15 January 1813 and GD113/5/464/172 7 January 1813.

${ }^{51}$ See Barclay, 'Natural Affection'.

${ }^{52}$ Rosalind Mitchison and Leah Leneman, Sexuality and Social Control: Scotland 1660-1780 (Oxford: Basil Blackwood, 1989), pp. 152-3.

${ }^{53}$ NRS GD113/5/30C/5 MP to Gilbert Innes, 26 March 1821.

${ }^{54}$ NRS GD113/5/473/130 A. Alexander to Gilbert Innes, 26 April 1819.

${ }^{55}$ NRS GD113/5/464/161.

${ }^{56}$ NRS GD113/5/472/72 A. Alexander to Gilbert Innes, 21 October 1818.

${ }^{57}$ NRS GD113/5/485/39 MP to Gilbert Innes, 6 November 1823.

${ }^{58}$ NRS GD113/5/490/104 MP to Gilbert Innes, 12 March 1825.

${ }^{59}$ NRS GD113/5/487/97 MP to Gilbert Innes, 21 June 1824; GD113/5/484/16 MP to Gilbert Innes, 2 April 1823; GD113/5/486/140 MP [Mary Hutton] to Gilbert Innes, 11 March 1824; GD113/5/486/134 MP to Gilbert Innes, 6 March 1824.

${ }^{60}$ NRS GD113/5/402/10 Note by Jane Innes, [no date].

${ }^{61}$ NRS GD113/5/487/69 MP to Gilbert Innes, 20 May 1824.

${ }^{62}$ NRS GD113/5/487/84 MP to Gilbert Innes, 2 December 1823.

${ }^{63}$ NRS GD113/5/484/29 MP to Gilbert Innes, 18 April 1823; GD113/5/487/95-97 MP to Gilbert Innes, 11, 16, 21 June 1824. 
${ }^{64}$ Quoted in Duncan, ‘Old Maids’, p. 194

${ }^{65}$ NRS GD113/5/464 Letters from William McLaurin to Gilbert Innes, 1813;

GD113/5/402/19 Copy correspondence, Gilbert Innes and George Burnet, 1807-1808.

${ }^{66}$ NRS GD113/5/483/35 George Burnet to Gilbert Innes, 30 January 1823; GD113/5/30C/1

MP [Mary Hutton] to Gilbert Innes, 8 May 1820; GD113/5/482/109 [Name torn off, probably

E. Crauford] to Gilbert Innes, 30 March [1822].

${ }^{67}$ NRS GD113/5/484/11 MP to Gilbert Innes, 8 April 1823

${ }^{68}$ NRS GD113/5/464/130 William Maclaurin to Gilbert Innes, 23 February 1813

${ }^{69}$ Duncan, ‘Old Maids’, pp. 180-6.

${ }^{70}$ NRS GD113/5/469/100 William Maclaurin to Gilbert Innes, 28 and 30 March 1815.

${ }^{71}$ GD113/5/469/84 Marion Burnet to Gilbert Innes, [7 March 1815]; GD113/5/469/110

Marion Burnet to Gilbert Innes, 24 March 1815.

${ }^{72}$ NRS GD113/5/30C/9 MP to Gilbert Innes, 15 October 1822.

${ }^{73}$ Barclay, Love, Intimacy, pp. 102-4; Joanne Bailey, 'Paternal Power: the Pleasures and Perils of 'Indulgent' Fathering in Britain in the Long Eighteenth Century', The History of the Family 17(3) (2012), pp. 326-42.

${ }^{74}$ For example, Nicola Phillips, 'Parenting the Profligate Son: Masculinity, Gentility, and Juvenile Delinquency in England, 1791-1814', Gender \& History 22(1) (2010), pp. 92-108.

${ }^{75}$ Barclay, Love, Intimacy, pp. 151-9.

${ }^{76}$ NRS GD113/5/105/25 Gilbert Innes to Jane Innes, 14 June 1793.

${ }^{77}$ NRS GD113/5/491/16 MP to Gilbert Innes, 7 April 1825.

${ }^{78}$ NRS GD113/5/491/53 MP to Gilbert Innes, 29 April 1825.

${ }^{79}$ NRS GD113/5/480/69 A. Alexander to Gilbert Innes, 21 November 1821. 